\title{
Литература
}

Метадычныя рэкамендаџыі па публікаџыі рукапісных актавых кірылічных крыніу у Беларусі (XIII-XVIII стст., перыяд Вялікага княства Літоўскага) / Аўтар-складальнік А. І. Груша. Мінск, 2003.

Полехов С. В. Привилеи великих князей литовских Смоленской земле / / Studia Slavica et Balcanica Petropolitana. 2015. № 1 (17). C. $115-140$.

Якубовский И. В. Земские привилеи Великого княжества Литовского. Ч. 2. Критический разбор текстов областных привилеев // ЖМНП. 1903. № 6. С. 245-303.

Tęgowski J. Kilka uwag o genealogii kniaziów Kroszyńskich do końca XV wieku / / Genealogia. Studia i Materiały Historyczne. Poznań; Wrocław, 2003. T. 15. S. 35-43.

Sergey V. Polekhov

Institute of Russian History of the Russian Academy of Sciences, Moscow, Russia

\section{ALEKSANDER JAGIELLOŃCZYK’S PRIVILEGE FOR THE SMOLENSK LAND (1505)}

The text of the privilege granted by the king of Poland and grand duke of Lithuania Aleksander Jagiellończyk is published from its original preserved in the Central Archives of Historical Records in Warsaw (Archiwum Główne Akt Dawnych) according to the modern principles of editing Ruthenian documents.

Keywords: Aleksander Jagiellończyk, Grand Duchy of Lithuania, land privileges, Smolensk land

УДК 94 (47) ББК 63.3.(2).43 DOI 10.25986/IRI.2019.75.1.0024

\author{
И. Г. Пономарева
}

МГЛУ, Москва, Россия. vasiliy_ii@mail.ru

\section{ОКРУЖЕНИЕ МОСКОВСКОГО ВЕЛИКОГО КНЯЗЯ ВАСИЛИЯ ІІ В НАЧАЛЕ ЕГО ПРАВЛЕНИЯ}

В статье анализируется ситуаџия, сложившаяся при московском великокняжеском дворе после начала самостоятельного правления Василия II. Приводятся известия о соответствуюших мероприятиях. Основной сюжет статьи связан с попыткой проверить выводы А. В. Черепнина. 1. В окружение великого князя вошли новые, молодые люди. 2. Эти изменения и новый политический курс привели к конфликту со старыми боярами.

Ключевые слова: Василий II, московский великокняжеский двор, великое княжество Московское в первой четверти $X V$ в., московские бояре

Историками многократно описан период правления московского великого князя Василия Темного, но при этом не обрашалось внимания на то, как началось его самостоятельное княжение.

Василий II унаследовал престол незадолго до своего 10 -летия и в первые годы управленческие функџии исполнял лишь номинально. Возмужание и переход к самостоятельной политической деятельности были ознаменованы рядом событий.

5 октября 1432 г. состоялось офиџиальное посажение на великокняжеский престол ${ }^{1}$.

Осенью (до или сразу после интронизаџии) Василиї II обручился² ${ }^{2}$ Брак был заключен 8 февраля следуюшего года ${ }^{3}$.

Надо думать, после интронизаџии был заключен ряд договоров ${ }^{4}$.

При оформлении великокняжеских грамот постепенно утверждается практика их удостоверения дьяками подписью «великий князь». Ю. Г. Алексеев посчитал это основным нововведением второго периода феодальной войны, очевидно, подразумевая периодизаџию Л. В. Черепнина, связавшего его со смертью 5 июня 1434 г. удельного князя Юрия Дмитриевича Галиџкого, оспаривавшего у Василия II престол [Алексеев, с. 70; Черепнин, 1960 , c. 763]. На самом деле, первый подобный акт был оформлен в 1432 или 1433 г. ${ }^{5}$

ᄉ. В. Черепнин, комментируя состоявшийся после обручения отъезд из Москвы к Юрию Дмитриевичу самого влиятельного члена великокняжеского двора - боярина Ивана Дмитриевича Всеволожского ${ }^{6}$, предположил, что

${ }^{1}$ ПСРЛ. М., 2007. Т. 27. С. 269, 344; ᄉ., 1982. Т. 37. С. 41, 85; M., 1994. Т. 39. С. 143.

2 ПСРЛ. М., 2001. Т. 6. Вып. 2. Стб. 64-65; М., 2004. Т. 25. С. 250; Т. 27. 269, 344. В древности начало сезонов увязывалось с различными приметами и праздниками, граниџы не были определенными. Самой ранней из дат начала осени было 20 июля, зимы -7 октября (Славянские древности. Этнолингвистический словарь. М., 1999. Т. 2. С. 327; М., 2004. Т. 3. C. 568).

${ }^{3}$ ПСРЛ. Т. 25. С. 250.

4 Были заключены или вероятна возможность заключения следуюших договоров: с Василием Ярославичем Серпуховским и Боровским (ДДГ. № 27. Заключен после смерти летом 1432 г. удельного князя Андрея Дмитриевича, вместо которого в договоре в числе династов фигурируют его сыновья. О датировке акта см. также: [Пресняков, с. 391-392, примеч. 3; Черепнин, 1948, с. 107-108; Зимин, с. 295-296; Кучкин, с. 69]); с Великим Новгородом (ГВНП. № 19; [Пономарева, 2018]); с Иваном Андреевичем Можайским и Михаилом Андреевичем Белозерским и Верейским [Пономарева, 2015]; с рязанским великим князем Иваном Федоровичем 1432 или 1433 г. (ДДГ. С. 448, 463).

5 АСЭИ. М., 1952. Т. І. № 74.

${ }^{6}$ ПСРЛ. Т. 6. Вып. 2. Стб. 64-65; Т. 27. 269, 344. 
этому предшествовали изменения в «московском правительстве», в котором «усилилась роль юных бояр»: боярин не согласился с курсом нового великокняжеского окружения, направленным на умаление прав удельных князей и аристократии [Черепнин, 1960, с. 755-756]. А. А. Зимин, напротив, находил, что в «боярской среде давно росло недовольство всевластием Всеволожского» [Зимин, с. 53]. Не согласуется с выводами $\mathcal{\lambda}$. В. Черепнина и мнение знатока истории служилых родов и служебных отношений С. Б. Веселовского, считавшего, что старые московские роды были естественными союзниками великих князей в борьбе за џентрализаџию власти [Веселовский, с. 514].

Появление в кругу молодого, только приступившего к управлению великого князя близких по возрасту и духу людей, его желание обозначить собственные политические устремления, к тому же не противоречашие обшему ходу исторического проџесса, логичны, но $\mathcal{\lambda}$. В. Черепнин не подкрепил свои выводы доказательствами. Прежде всего, необходимо установить, были ли изменения в составе «правительства» в первые годы после утверждения Василия II на престоле. Если таковые будут обнаружены, то выявленный состав лиџ позволит поставить вопрос о вероятности смены политического курса.

В первые годы после смерти Василия I в круг ближних бояр его наследника входили: князь Юрий Патрикеевич, Иван Дмитриевич Всеволожский, Иван Федорович Кошкин, Федор Иванович Сабур, Александр Владимирович Лыков [Пономарева, 2011] и, надо думать, Федор Михайлович Челяднин, хотя служба последнего фиксируется не ранее 1433 г. ${ }^{7}$ Отеџ Федора Михайловича был в числе свидетелей последних завешаний Василия I, но после его смерти Михаил Андреевич Челядня источниками не упоминается. Вместе с тем Ф. М. Челяднин с 1430-х годов виден как выдаюшйсся член Двора. Скорее всего, он ранее 1432 г., будучи еше молодым человеком, преемственно занял место выбывшего по немоши или из-за смерти отџа. Не прослеживается при Василии II деятельность и Федора Ивановича Сабура, очевидно также сошедшего с политической арены по естественным причинам.

Единственные фиксируемые изменения в боярской верхушке в 1432 г. связаны с отъездом И. Д. Всеволожского, к которому присоединился А. В. Аыков ${ }^{8}$.

Главой московского боярства по-прежнему остался князь Юрий Патрикеевич. В 1433 г. он возглавлял великокняжеский поход против сыновей Юрия Дмитриевича Галиџкого9. ФФедор Михайлович Челяднин подписал

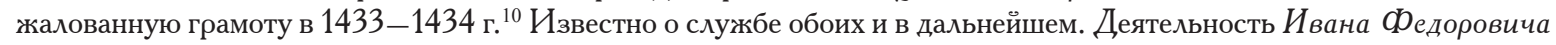
Кошкина в 1430-е годы не подтверждается строго. Так, нельзя сказать, когда была оформлена подписанная Иваном Федоровичем недатированная жалованная грамота Чудову монастырю ${ }^{11}$, но сохранились 4 грамоты 1440 -х годов Софьи Витовтовны, матери Василия II, за подписью Ивана Федоровича, очевидно завершавшего карьеру при великой княгине ${ }^{12}$. Это обстоятельство косвенно свидетельствует в пользу того, что в 1430 -е годы И. Ф. Кошкин служил при великокняжеском дворе.

По жалованным грамотам выявляются еше несколько человек, имевших отношение к их выдаче и, следовательно, причастных к управлению княжеством.

Фредор Андреевич подписал 2 жалованные грамоты (один акт - 1433 или 1434 г., второй акт не датирован $)^{13}$. Идентификаџия Ф Федора Андреевича затруднена, но в комментариях при публикаџии актов И. А. Голубџовым и С. М. Каштановым высказано предположение, что речь может идти о двух полных братьях-тезках из рода Ратши с прозвищами: Ложь и Старка (вар.: Старко). В комментарии к первому акту предпочтение отдано Старке, а ко второму - ᄉже. Думается, что применительно к актам речь должна идти об одном лиџе, и более вероятен упоминаемый летописью как участник переговоров в 1433 г. с Юрием Галиџким - Ложь.

С начала 1430-х годов сплоченно входят в круг управленџев высших звеньев по меньшей мере четверо братьев Добрынских. В 1420 г. старший из них (Андрей) был боярином угличского удельного князя ${ }^{14}$. ФФедор известен как походный воевода в конџе 1428 - начале 1429 г. $^{15}$ К оформлению жалованных грамот в 1430-е годы ${ }^{16}$ могли иметь отношение сразу 4 брата. Андрей Константинович, Петр Константинович и Иван Константинович подписывали грамоты (1435, 1436 и 1432 1445 г. $)^{17}$. Младший из братьев - Никита - отметился как распорядитель оформления двух актов (1432-

7 Подписал жалованную грамоту 1433 или 1434 г. (АСЭИ. М., 1964. Т. ІІІ. № 99).

825 апреля - 28 сентября 1433 г. Иван Дмитриевич и Александр Владимирович как бояре Юрия Галиџкого подписали его жалованную грамоту (Антонов А. В., Баранов К. В. Неизвестные акты XIV-XVI веков из архива Московского Чудова монастыря // Русский дипломатарий (далее - РД). М., 1997. Вып. 2. С. 12. № 3. Идентификаџия Лыкова и датировка на c. 5-6)

${ }^{9}$ ПСРЛ. Т. 25. С. 51.

${ }_{10}^{10}$ АСЭИ. Т. III. № 99.

11 Материалы к каталогу актов Русского государства. Вотчинные архивы московских монастырей и соборов XIV начала XVII века (Антонов А. В.) // РД. Вып. 2. С. 81. № 11.

12 Антонов А. В., Баранов К. В. Акты из архивов русских монастырей и шерквей // РД. М., 1998. Вып. 3. С. 34-35. № 25; АСЭИ. Т. І. № 217, 218; М., 1958. Т. II. № 323.

13 АСЭИ. Т. ІІ. № 439; Каштанов С. М. Очерки русской дипломатики. М., 1970. С. 346. № 4.

${ }^{14}$ ПСРЛ. Т. 25. С. 245.

15 ПСРЛ. Т. 25. С. 248; Т. 39. С. 143.

16 Часть недатированных актов Троиџе-Сергиева монастыря, упоминаюших Добрынских, отнесена к широкому временному промежутку (1432-1445 г.) по игуменству Зиновия.

17 АСЭИ. Т. І. № 105, 117, 128. 
1445 г.), о чем свидетельствуют приписки к ним: «А приходил Никита Констянтиновичь» и «А приказал Микита Костантинович» ${ }^{18}$. В 1433 г., очевидно до перехода на службу в Москву, Петр был наместником в $\rho_{\text {остове }}{ }^{19}$. Никита в какой-то период службы у Василия II наместничал в Переяславле ${ }^{20}$.

Доверенными лиџами Василия II, несомненно, были его послы.

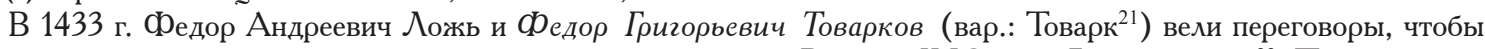
предотвратить боевые действия с выступившим в поход против Василия II Юрием Дмитриевичем ${ }^{22}$. После победы

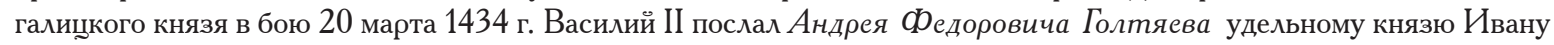
Андреевичу Можайскому с просьбой сохранять верность.

Включение в круг управленџев лиџ, известных только по участию в боевых действиях, едва ли будет корректным.

Теперь можно сравнить людей из ближайшего окружения Василия II до и в первые годы после начала его самостоятельного правления.
1. Юрий Патрикеевич
2. Иван Дмитриевич Всеволожский
3. Иван Федорович Кошкин
4. Федор Иванович Сабур
5. Александр Владимирович Лыков
6. Федор Михайлович Челяднин
1. Юрий Патрикеевич
2. Иван Федорович Кошкин
3. Федор Михайлович Челяднин
4. Андрей Фредорович Голтяев
5. Федор Андреевич Ложь
6. Федор Григорвевич Товарков
7-10. Андрей, Петр, Иван, Никита Константиновичи Добрынские

Кем были новые лиџа (выделены курсивом)? Было ли получение ими высоких должностей нормальным с точки зрения практики назначений, или имело место пренебрежение традиџиями? Второй вариант мог, с одной стороны, спровоџировать недовольство старых бояр и Двора в џелом, с другой - способствовать нововведениям в политическом курсе, как предполагал $\lambda$. В. Черепнин.

Абсолютно понятно возвышение дяди жены Василия II - Андрея Федоровича Голтяева из рода Кошкиных, выдвинувшихся и закрепившихся в первых рядах еше при Василии I. Сам Андрей Голтяев был в относительно молодом возрасте, будучи младшим из братьев (известно, что старший - Иван, находившийся в свите Василия II, умер юным в 1426 г.23).

Появление других новых лиџ в ближайшем окружении Василия II объяснить сложнее.

Федор Григорьевич Товарков, хотя и принадлежал к Морхининым, старшей ветви Ратшичей, входивших в круг старомосковских служилых родов, был ее младшим членом [Веселовский, с. 40, примеч. 1; Кузьмин, с. 240 ]. При этом младшая ветвь Акинфовичей, к которой, в частности, относился Ф. М. Челяднин, изначально занимала в московской иерархии более высокое положение.

О родовом статусе Федора Андреевича Лжи судить нельзя, так как его происхождение неясно (А. В. Кузьминым высказано и обосновано предположение о его принадлежности к Морхининым [Кузьмин, с. 236-246]). Можно лишь отметить, что, упоминая обоих бояр, летописеџ первым записал Федора Андреевича, что предполагает его старшинство.

Возможно, появление Морхининых рядом с Василием II связано с протекџией их однородџа Ф. М. Челяднина. Потеряв старших 6 ратьев $^{24}$ и пока не имея взрослых детей, он мог, опираясь на родню, усилить свои позиџии при дворе.

В преуспевании Добрынских, чьи предки не замечены в «больших» боярах, возможно, сыграло свою роль свойство с известными родами. Федор женился на дочери Дмитрия Васильевича, боярина Василия I, по мнению С. Б. Веселовского, Ратшича [Веселовский, с. 433]. Через ее сестер Добрынские оказались в родстве с Морозовыми и Бяконтовыми ${ }^{25}$.

Нельзя исключить возможность выдвижения некоторых из названных лиџ, тех же Добрынских, как ровесников Василия II, с которыми его связывали дружественные отношения. Возраст Лжи и Товаркова не определяется, но младшие Добрынские в 1430-е годы вполне могли быть еше молодыми людьми. В частности, Петр был жив в первой половине 1460 -х годов ${ }^{26}$.

Итак, материалы источников не позволяют уверенно сделать какие-либо однозначные выводы относительно изменений в ближнем окружении Василия II после его вступления на престол. Несомненно, осталась часть прежних

\footnotetext{
18 Там же. № 84, 95.

${ }^{19}$ ПСРЛ. Т. 25. С. 250; Т. 27. С. 104.

20 АСЭИ. Т. III. № 83.

21 Румянџевская редакџия родословных книг // Редкие источники по истории России (далее - РИИР). М., 1977. Вып. 2. C. 130.

22 ПСРЛ. Т. 25. С. 250.

23 Летописная редакџия родословных книг // РИИР. Вып. 2. С. 46-47; Румянџевская редакџия родословных книг. С. 154; ПСРЛ. М., 1980. Т. 35. С. 33, 56.

${ }_{24}$ Об их деятельности информаџии нет, понятно также, что занять место отџа Федор мог только в их отсутствие.

${ }_{25}$ Типографский родословеџ // ПСРЛ. М., 2000. Т. 24. С. 231-232.

${ }_{26}$ Он привлекался к следствию по местническому делу 1463-1464 г. [Назаров, с. 181-182, 186, 188].
} 
бояр. Вместе с тем появились и, возможно, даже преобладали в кругу «больших» бояр новые, среди которых были молодые и относительно молодые люди, представители не только семей, но и родов (во всяком случае, Добрынские), не входивших ранее в число первостепенных. Теоретически это могло вызвать напряжение при дворе.

В это время фиксируются конфликтные ситуаџии с участием лиџ из великокняжеского окружения. На свадьбе великого князя старший сын Юрия Галиџкого был уличен в том, что надетый на нем драгоџенный пояс краденый. Летописи называют имена двух иниџиаторов скандала: двоюродного дядю невесты Захария Ивановича Кошкина и Петра Константиновича Добрынского 27 . Оскорбленные сыновья Юрия Дмитриевича покинули свадебные торжества и прибыли к отџу, после чего он выступил в поход против Василия II. Тот направил к нему Федора Лжу и Федора Товаркова, но во время переговоров Юрий Дмитриевич их демонстративно покинул, а между оставшимися, среди которых был И. Д. Всеволожский, развернулась перепалка. Стороны не скрывали эмоџий и в выражениях не стеснялись: «бысть межи... бояръ брань велика и слова неподобные» ${ }^{28}$.

Скандал на свадьбе, дискредитирующй галиџких князей, непосредственно с отношениями внутри великокняжеского окружения не связан, но демонстрирует активность и напористость, присушую некоторым его членам из «новых» и «молодых». В основе второго конфликта, возможно, лежала взаимная неприязнь, о причинах которой можно только гадать. В любом случае, отъезд И. Д. Всеволожского был вызван личными мотивами ${ }^{29}$. Провалился его план породниться с великим князем. Выбранная в жены Василию II княжна Мария Ярославна из серпуховской ветви московского княжеского дома была в родстве с Кошкиными, что гарантировало их дальнейшее проџветание в ушерб другим. Не исключено, что ситуаџия вокруг брака была использована великокняжеской семьей для удаления претенџиозного боярина. Но полной уверенности в последнем быть не может, как нет и прямых доказательств ни џеленаправленного обновления Василием II боярства в начале 1430-х годов, ни проявлений в это время принџипиально нового политического курса. Нет никаких оснований считать, что утратила влияние мать Василия II, несколько лет исполнявшая функџии регента при малолетнем сыне, что скорее способствовало преемственности в политике, чем ее резкой смене. Отъем в 1432 г. у Юрия Дмитриевича Дмитрова ${ }^{30}$ и ссора с его сыновьями могут свидетельствовать о том, что великокняжеская семья была настроена действовать решительно в отношении притязаний Галиџкой ветви удельных князей, но в этом не было угрозы для московской аристократии, как полагал Л. В. Черепнин, скорее наоборот: центральная власть нуждалась в ее поддержке ${ }^{31}$.

По всей видимости, в первые месяџы и годы самостоятельного правления Василия II в его деятельности более или менее органично сочетались преемственность и новизна. При этом несомненно стремление взрослевшего великого князя к самоутверждению в роли правителя княжества, которое все его окружение могло использовать для собственного благополучия и возвышения.

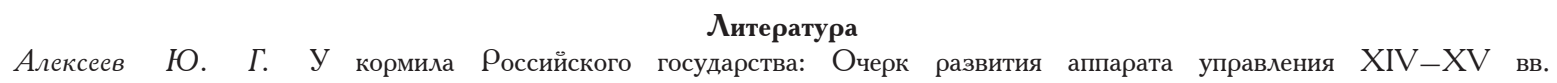
СПб., 1998.

Веселовский С. Б. Исследования по истории класса служилых землевладельџев. М., 1969.

Зимин $A$. А. Витязь на распутье: Феодальная война в России XV в. М., 1991.

Кузьмин А. В. На пути в Москву. М., 2015. Т. II.

Кучкин В. А. Московско-серпуховские договоры второй - начала третьей четверти XV в. // Древняя Русь. Вопросы медиевистики. 2017. № 3 (69). С. 69-70.

Назаров B. Д. Разыскания о древнейших грамотах Троиџе-Сергиева монастыря. III. Троиџкий стареџ Геннадий Бутурлин // Восточная Европа в исторической ретроспективе. К 80-летию В. Т. Пашуто. М., 1999. С. 180 -189. Полевой Н. А. История русского народа. М., 1833. Т. 5.

Пономарева И. Г. Кто управлял Московским великим княжеством в 1425-1432 гг. // Средневековая Русь. М., 2011. Вып. 9. С. 167-196.

Пономарева И. Г. К датировке первого договора московского великого князя Василия II с удельными князьями Иваном Андреевичем Можайским и Михаилом Андреевичем Верейским // Вспомогательные исторические дисџиплины и источниковедение: современные исследования и перспективы развития. Материалы XXVII Междунар. научной конф. Москва. 9-11 апреля 2015 г. М., 2015. С. 362-364.

Пономарева И. Г. К датировке «первого» договора Василия II с Новгородом // Вспомогательные исторические дисџиплины в современном научном знании. Материалы XXXI Междунар. научной конф. Москва, 12-14 апреля 2018 г. М., 2018. С. 303-306.

Пресняков А. Е. Образование Великорусского государства. Пг., 1918.

Соловьев С. М. История России с древнейших времен. 2-е изд. СПб., б. г. Кн. I. Т. I-V.

Черепнин А. В. Русские феодальные архивы XIV-XV вв. М.; Л., 1948. Ч. 1.

Черепнин А. В. Образование Русского џентрализованного государства в XIV-XV веках. М., 1960.

${ }_{27}$ ПСРЛ. Т. 6. Вып. 2. Стб. 65; СПб., 1910. Т. 20. Ч. 1. С. 238; М., 2004. Т. 23. С. 147; Т. 25. С. 250; Т. 27. С. 269-270, 344; М.; ᄉ., 1963. T. 28. C. 99, 265; T. 37. C. 41, 85; T. 39. C. 143.

${ }_{28}$ ПСРЛ. Т. 25. С. 250.

29 Так считали все, кто комментировал этот сюжет [Шербатов, с. 460; Полевой, с. 300-301; Соловьев, стб. 1054-1055; Экземплярский, с. 156; Веселовский, с. 340, 510; Зимин, с. 49-50].

${ }_{30}$ ПСРЛ. М., 2000. Т. 12. С. 17; Т. 24. С. 182; Т. 25. С. 250; Т. 27. С. 269, 344.

${ }^{31}$ С. Б. Веселовский также полагал, что великокняжеская власть в это время решала «историческую задачу», сосредоточившись на борьбе с удельными князьями, в которой служилым людям отводилась роль не ее противников, а союзников [Веселовский, c. 307]. 


\section{М. Б. Свердлов}

Шербатов М. М. История российская от древнейших времен. СПб., 1781. Т. IV. Ч. I.

Экземплярский A. В. Великие и удельные князья Северо-Восточной Руси в татарский период с 1238 по 1505 г. СПб., 1889. T. I.

Irina G. Ponomareva

Moscow State Linguistic University, Moscow, Russia

\section{THE ENTOURAGE OF GRAND PRINCE OF MOSCOW VASILY II AT THE BEGINNING OF HIS REIGN}

The article analyzes the situation prevailing at the court of the Grand Prince of Moscow after the beginning of the independent reign of Vasily II. There is news about relevant events. The essence of the article is connected with an attempt to verify the conclusions of L. V. Cherepnin. 1. The entourage of the Grand Prince included new, young people. 2. These changes and the new political course led to a conflict with the old boyars.

Keywords: Vasily II, court of the Grand Prince of Moscow, Grand Principality of Moscow in the first quarter of the $15^{\text {th }}$ century, boyars of Moscow

УДК 217, 281,9, 291,35 ББК 86, 372 DOI 10.25986/IRI.2019.75.1.0025

М. Б. Свердлов

Санкт-Петербургский институт истории $Р A H$,

Российский государственный педагогический университет им. А. И. Гериена,

Санкт-Петербург,

\section{К ИЗУЧЕНИЮ ХОР НОВГОРОДСКИХ ХРАМОВ ХІ - ПЕРВОЙ ТРЕТИ ХІІ в.}

Статья посвящена изучению проблемы назначения хор и определению места князя во время богослужения в новгородских храмах XI - первой трети XII в. Эта тема исследована в контексте византийской традиџии и ее русской модификаџии.

Ключевые слова: богослужение, храмы, хоры, князья, византийская традиция, русская модификация

Научный анализ назначения хор и определения места князя во время богослужения в древнерусских храмах стал осушествляться лишь в конџе XIX - начале XX в. По мнению Е. Е. Голубинского, на верхних галереях џерквей находились только женшины [Голубинский, с. 239-243]. Впрочем, тогда же знаток византийских древностей Д. ср. Беляев установил, что император в сопровождении синклита отправлялся в Св. Софию, используя переходы Магнавры, одного из зданий Большого дворџа. Затем совершалось торжественное шествие до Св. Софии. Там совместно с патриархом император принимал участие в литургическом действе, включавшем его присутствие в алтаре. В южных галереях, нижней и верхней, Св. Софии находилось по мутаторию - помешению, в которых во время литургии император облачался и переоблачался, слушал длительную службу, отдыхал и завтракал. В мутаторий южной галереи он поднимался во время литургии и выходил оттуда только для причастия Св. Тайн. Там император принимал причастие от патриарха или других свяџенников. На южных хорах он находился и в других храмах. Там во время литургии он пребывал невидимо для прочих моляшихся, но все видел и слышал. По мнению Д. Ф. Беляева, во время богослужения женшины находились на западной и преимушественно северной галерее [Беляев, 1892, с. 90-145, 209-210; Беляев, 1893, с. 134, 238, 239, 245-246].

Такие наблюдения стали основанием для широко распространенного в советской историографии вывода о нахождении князя во время богослужения на южных хорах в соответствии с его особым соџиальным и политическим статусом. Впрочем, это мнение излагалось подчас в идеологизированной или вульгаризированной форме. Зарубежные ученые также писали о южной верхней галерее как предназначенной для императора, однако, в соответствии с позитивистскими принџипами, только констатируя этот факт.

В постсоветской историографии эти наблюдения стали подвергаться критике. А. А. Голубева повторила мысль о нахождении на хорах только женшин. Она предположила, что князь находился там «в качестве частного лиџа, а не главы государства», совершая частные службы [Голубева] $]^{1}$.

Э. А. Гордиенко поддержала мнение С. В. Заграевского, в соответствии с которым хоры расширяли полезную площадь храма для использования в самых разных џелях. Она обоснованно сочла невозможным исполнение русским князем византийского церковного ритуала. Поэтому Э. А. Гордиенко предположила существование в русском православном ритуале XI в. древнего обычая стояния князя перед алтарем с дружиной, семьей, немногочисленными тогда христианами. Но на южной стороне хор Софии Новгородской находились княжеские палаты, включая мутаторий, откуда князь слушал службу, наблюдая за действом в предалтарном пространстве. На хорах были также помешения для сопровождавших князя духовных чинов, для нужд храма и Новгорода.

По мнению Э. А. Гордиенко, в новгородских княжеских џеркви Благовешения на Городише (1103) и Никольском соборе на Ярославовом дворише (1113) князь с семьей и дружиной не могли находиться во время литургии на хорах. Они стояли во время службы у алтаря вместе с народом. Но она допустила, что князь мог оставаться на хорах, когда не ходил к причастию. На хорах Никольского собора могли проходить заседания смесного суда, духовного синклита, помешаться канџелярия князя и книгохранительниџа [Гордиенко, с. 116-119].

1 В данной работе и в трудах последующих авторов см. указания значительной научной литературы на данные темы. 